\title{
Peptides from American alligator plasma are antimicrobial against multi-drug resistant bacterial pathogens including Acinetobacter baumannii
}

\author{
Stephanie M. Barksdale ${ }^{1}$, Evelyn J. Hrifko², Ezra Myung-Chul Chung ${ }^{3,4}$ and Monique. L. van Hoek ${ }^{1,3^{*}}$
}

\begin{abstract}
Background: Our group has developed a new process for isolating and identifying novel cationic antimicrobial peptides from small amounts of biological samples. Previously, we identified several active antimicrobial peptides from $100 \mu$ of plasma from Alligator mississippiensis. These peptides were found to have in vitro antimicrobial activity against Pseudomonas aeruginosa and Staphylococcus aureus. In this work, we further characterize three of the novel peptides discovered using this process: Apo5, Apo6, and A1P.

Results: We examined the activity of these peptides against multi-drug resistant strains and clinical isolates of common human pathogens. We investigated their structural characteristics using circular dichroism and tested for membrane disruption and DNA binding. These peptides were found to have strong in vitro activity against multi-drug resistant and clinically isolated strains of S. aureus, Escherichia coli, P. aeruginosa, and Acinetobacter baumannii. Apo5 and Apo6, peptides derived from alligator apolipoprotein C-1, depolarized the bacterial membrane. A1P, a peptide from the serpin proteinase inhibitor, did not permeabilize membranes. Performing circular dichroism analysis, Apo5 and Apo6 were found to be predominantly helical in SDS and TFE buffer, while A1P has significantly different structures in phosphate buffer, SDS, and TFE. None of these peptides were found to be hemolytic to sheep red blood cells or significantly cytotoxic up to $100 \mu \mathrm{g} / \mathrm{ml}$ after $24 \mathrm{~h}$ exposure.
\end{abstract}

Conclusions: Overall, we suggest that Apo5 and Apo6 have a different mode of action than A1P, and that all three peptides make promising candidates for the treatment of drug-resistant bacteria, such as A. baumannii.

Keywords: Antimicrobial peptides, Alligator mississippiensis, Multi-drug resistant bacteria, Acinetobacter baumannii, Escherichia coli, Staphylococcus aureus

\section{Background}

Cationic antimicrobial peptides (CAMPs) are short proteins produced by the innate immune system of virtually all eukaryotic organisms [1]. CAMPs have a variety of structures, such as helical, beta-sheet, or mixed structures [2], and antibacterial mechanisms, including membrane perturbation [3], DNA binding [4], and enzyme interference [5]. There has been strong interest in the

\footnotetext{
* Correspondence: mvanhoek@gmu.edu

${ }^{1}$ School of Systems Biology, George Mason University, Manassas, VA, USA

${ }^{3}$ National Center of Biodefense and Infectious Diseases, George Mason

University, 10920 George Mason Cir, 10920 George Mason Circle, MSN 1H8,

Manassas, VA 20110, USA

Full list of author information is available at the end of the article
}

discovery and exploration of CAMPs due to rising drug resistance in pathogenic bacteria and the subsequent need for new therapeutics [1]. Traditionally, new CAMPs are identified through either bioinformatics or fractionation. CAMPS are a diverse group of peptides that can differ by nucleic acid sequence, amino acid sequence, and secondary structure [2], which can complicate the process of locating new CAMPs by analysis of gene and protein databases. Fractionation through HPLC or other methods typically requires large amounts of biological sample, usually a liter or more [6], which can be problematic when working with small or endangered animals. Fractionation and testing can also be challenging 
due to dilution of samples, as CAMPs can be present in very small amounts $[6,7]$.

Our group recently developed a novel and powerful process for discovering and identifying new and potentially useful CAMPs from biological samples, called the Bioprospecter process [8]. Our CAMP discovery process is sample-agnostic and requires very small sample volumes for analysis. We have successfully employed this process to discover a large number of new peptides from $100 \mu \mathrm{l}$ of plasma from the American alligator, Alligator mississippiensis; five of these show antibacterial activity against Gram-positive and/or Gram-negative bacteria. Moreover, it is unique in its approach to CAMP identification in that it directly mines the native antimicrobial peptidome through custom-made hydrogel particles whose properties complement the physico-chemical properties of CAMPs [8]. This bioprospecting approach provides us access to the CAMP peptidomes of some of the world's most remarkable species, to dramatically expand the current CAMP library and potentially unlock the key to overcoming antibiotic resistance via the discovery of new antimicrobial peptides.

Using this tool, we previously described three novel peptides from A. mississippiensis (Apo5, Apo6, and A1P) with activity against laboratory strains of E. coli, P. aeruginosa, S. aureus, and Bacillus cereus [8]. Apo5 and Apo6 are highly related peptides; nested fragments of a purported apolipoprotein. Apolipoproteins have antimicrobial activity against a variety of pathogenic bacteria [9-14] (see Discussion). A1P is the C-terminal fragment of alpha-1-proteinase inhibitor of the serpin family; this protease inhibitor has broad protease inhibiting activity, as well as immunomodulatory effects [15]. In this work, we further characterize the antimicrobial activity of these peptides against bacterial pathogens resistant to multiple antibiotics as well as clinical isolates, including multidrug resistant A. baumannii, which was not previously tested. In addition, we sought to determine the secondary structure of these peptides in order to understand the mechanism by which they exert their antibacterial activity.

\section{Methods}

\section{Bacteria}

Staphylococcus aureus ATCC 33592 (MDR) and BAA1718, Escherichia coli ATCC 51659 (MDR) and 4157, Pseudomonas aeruginosa ATCC BAA-2110 (MDR), and Acinetobacter baumannii ATCC BAA-1794 (MDR) and 9955 were purchased from the American Type Culture Collection (Manassas, VA). Pseudomonas aeruginosa strain PAO1 was generously provided by Karin Sauer from Binghamton University (Binghamton, NY). All strains are clinical isolates except for E. coli ATCC 4157. Bacteria were grown in Nutrient Broth (Difco 234000) overnight in a shaking incubator $\left(37^{\circ} \mathrm{C}\right)$. Bacteria were aliquoted and frozen at $-80^{\circ} \mathrm{C}$ and enumerated via serial dilution and plating prior to experimentation.

\section{Peptides}

All peptides were synthesized to order by ChinaPeptides, Inc (Shanghai, China) using Fmoc chemistry. Peptides were provided at $>95 \%$ purity, and purity and structure were confirmed with RP-HPLC and ESI-MS.

\section{Bioinformatics}

Physiochemical properties were calculated using the Antimicrobial Peptide Database (APD2) [16]. The percent hydrophobicity is defined as the ratio of hydrophobic residues to total residues. The full-length sequences for the apolipoprotein C-1 containing Apo5 and Apo6 (Accession XP_006276575.1) and for the alpha-1proteinase containing A1P (Accession XP_006266331.1) were found on the BLAST NCBI database [17]. Ribbon models displaying the full proteins were created using SWISS MODEL [18-20]. The A. mississippiensis apolipoprotein $\mathrm{C}-1$ was modeled on the human apolipoprotein C-1 (SMTL id: 1ioj.1.A, Sequence identity $=43.40 \%$ ), and the A. mississippiensis alpha-1-proteinase was modeled on alpha1-antitrypsin (SMTL id: 3dru.1.A, Sequence identity $=51.41 \%)$ [18-23]. The secondary structure of Apo5, Apo6, and A1P was predicted using ITASSER [24] and visualized with Chimera [25]. Helical wheel projections and hydrophobic moment were calculated using HeliQuest [26].

\section{Circular dichroism spectroscopy}

Circular dichroism (CD) was performed using a Jasco J1500 spectropolarimeter. $100 \mu \mathrm{g} / \mathrm{ml}$ of peptide was used in each experiment. Samples were allowed to equilibrate for $3 \mathrm{~min}$ prior to data collection at $25{ }^{\circ} \mathrm{C}$ in a $1 \mathrm{~mm}$ path length cuvette. Spectra were collected from 190 to $260 \mathrm{~nm}$ at $0.2-\mathrm{nm}$ intervals, with a data integration time of $4 \mathrm{~s}$ and a $1 \mathrm{~nm}$ bandwidth. Data presented is an average of four spectra. Peptides were analyzed in $10 \mathrm{mM}$ sodium phosphate buffer $(6.12 \mathrm{mM}$ sodium monohydrogen phosphate heptahydrate; $3.92 \mathrm{mM}$ monosodium phosphate anhydrous; $\mathrm{pH} 7.4), 50 \%(\mathrm{v} / \mathrm{v})$ trifluoroethanol (TFE) in phosphate buffer, or $60 \mathrm{mM}$ sodium dodecyl sulfate (SDS) in phosphate buffer. Percent contribution to secondary structure was measured using methods determined by Raussens et al. [27].

\section{Antimicrobial assays}

The antimicrobial MIC activity of the peptides was first determined in cation-adjusted Mueller Hinton Broth (BD 212322) in a 96 well plate following the CLSI protocol. Enumerated bacteria were diluted in broth and $10^{5} \mathrm{CFU}$ was added to each well with 
varying dilutions of peptide. The plate was incubated for $24 \mathrm{~h}$ at $37{ }^{\circ} \mathrm{C}$ and then read on a spectrophotometer at $\mathrm{OD}_{600} \mathrm{~nm}$.

The $\mathrm{EC}_{50}$ antibacterial activity of the peptides was determined in $10 \mathrm{mM}$ phosphate buffer using resazurin as an indicator of CFU as previously described and validated by Bishop et al. [8] or by colony counting. The sequences and net charges of the peptides tested are shown in Table 1 . In a polypropylene 96 well plate, $10^{5}$ bacteria were incubated in $10 \mathrm{mM}$ phosphate buffer with various dilutions of peptide $\left(3 \mathrm{~h} ; 37^{\circ} \mathrm{C}\right)(1: 5)$. For the resazurin method, cation-adjusted Mueller Hinton Broth (BD 212322, final concentration $2.2 \%$ ) and resazurin (final concentration $109 \mu \mathrm{M}$ ) dissolved in PBS were added to each well, and the plate was read kinetically overnight on a Tecan Safire ${ }^{2}$ spectrofluorometer $\left(37^{\circ} \mathrm{C}\right.$; excitation $=540 \mathrm{~nm}$; emission $=590 \mathrm{~nm}$ ). Percent survival after treatment was then calculated with previously determined growth curves (Table 2). For colony counting, experimental wells were serially diluted after incubation, and $8 \mu \mathrm{l}$ of each dilution was spotted onto cation-adjusted Mueller Hinton Agar (BD 211438) and allowed to dry. Agar plates were then incubated overnight at $37^{\circ} \mathrm{C}$. After incubation, colonies were counted and percent survival was calculated based on untreated bacteria. GraphPad Prism 6.0 was used to calculate $\mathrm{EC}_{50}$ using $\log$ concentration vs. percent survival. LL-37, polymyxin B (against Gram-negative bacteria), and vancomycin (against Grampositive bacteria) are used as controls. LL-37 is a wellstudied human CAMP with broad-spectrum antimicrobial activity, polymyxin $\mathrm{B}$ is a peptide antibiotic effective against Gram-negative bacteria, and vancomycin is a peptide antibiotic used against Gram-positive bacteria. Each experiment was repeated at least twice, and a representative experiment is shown. $95 \%$ confidence intervals (CI) are reported to indicate the error of each $\mathrm{EC}_{50}$ determination.

\section{Ethidium bromide uptake assay}

The ethidium bromide uptake assay was performed as previously detailed $[28,29]$ with some modifications. $E$. coli ATCC 51659 was grown overnight in cationadjusted Mueller Hinton Broth in a shaking incubator $\left(37^{\circ} \mathrm{C}\right)$. Bacteria was centrifuged, washed with PBS, and then adjusted to an $\mathrm{OD}_{600} \mathrm{~nm}$ of 0.1 in $10 \mathrm{mM}$ phosphate buffer. $180 \mu \mathrm{l}$ of bacteria was added to $10 \mu \mathrm{l}$ ethidium bromide (10 $\mathrm{mM}$ final concentration) and $10 \mu \mathrm{l}$ peptide in various concentrations. The plate was read in a Tecan Safire ${ }^{2}$ spectrofluorometer every $2 \mathrm{~min}$ for $30 \mathrm{~min}\left(37{ }^{\circ} \mathrm{C}\right.$; excitation $=540 \mathrm{~nm}$; emission $=$ $590 \mathrm{~nm})$. Peak RFU at $50 \mu \mathrm{g} / \mathrm{ml}$ was used in Fig. 5.

\section{Membrane depolarization study}

Membrane depolarization was studied using $\operatorname{DiSC}_{3}(5)$ as has previously been reported [30]. Depolarization of a membrane can be visualized by a drop in fluorescence. Enumerated frozen bacteria were pelleted and washed twice in $10 \mathrm{mM}$ phosphate buffer and then resuspended to $4 \times 10^{7} \mathrm{CFU} / \mathrm{ml}$ in $10 \mathrm{mM}$ phosphate buffer containing

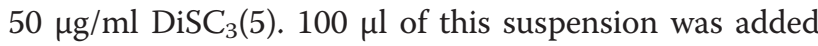
to wells of a black 96 well plate. The plate was incubated in a Tecan Safire ${ }^{2}$ spectrofluorometer and monitored until fluorescence leveled off. $100 \mu \mathrm{l}$ of various concentrations of peptide in $10 \mathrm{mM}$ phosphate buffer was added to each well. Bacteria without peptide and peptide without bacteria served as controls. The plate was immediately returned to the spectrofluorometer. Readings were taken every $15 \mathrm{~s}$ for $5 \min$ (excitation $=622 \mathrm{~nm}$; emission $=670 \mathrm{~nm}$ ). Peak RFU at each concentration was used in Fig. 6.

\section{Gel shift assay}

Non-specific DNA-peptide binding was determined by a gel-retardation experiment as described by Park et al. [4]. Briefly, $200 \mathrm{ng}$ of plasmid DNA (pTrcHis, Invitrogen V36020) was incubated with increasing concentrations of peptides in $20 \mu \mathrm{l}$ of binding buffer ( $5 \%$ glycerol, $10 \mathrm{mM}$ Tris- $\mathrm{HCl}$ [pH 8.0], $1 \mathrm{mM}$ EDTA, $1 \mathrm{mM}$ DTT, $20 \mathrm{mM} \mathrm{KCl}$ and $50 \mu \mathrm{g} / \mathrm{ml} \mathrm{BSA}$ ) at room temperature for $20 \mathrm{~min}$ and subjected to electrophoresis on a $1.0 \%$ agarose gel. DNA bands were visualized by ethidium bromide staining.

\section{Hemolysis and MTT assays}

To measure the hemolytic activity of peptides, $2 \%$ sheep red blood cells were added to various dilutions of peptide reconstituted in PBS in a sterile U-bottom 96 well plate. $2 \%$ RBCs with PBS $1 \mathrm{X}$ alone served as the negative control, and $2 \% \mathrm{RBC}$ in water as the positive control. The plate was incubated for $1 \mathrm{~h}$ at $37^{\circ} \mathrm{C}$ and then

Table 1 Amino acid sequences and molecular weights of selected peptides (identified in [8])

\begin{tabular}{llcccc}
\hline Peptide name & Sequence & Molecular weight & Charge & Hydrophobicity & Length \\
\hline Apo5 APOC1 $1_{64-88}$ & FSTKTRNWFSEHFKKVKEKLKDTFA & 3103.57 & +4 & $32 \%$ & 25 \\
Apo6 APOC1 $1_{67-88}$ & KTRNWFSEHFKKVKEKLKDTFA & 2766.49 & +4 & $31 \%$ & 22 \\
A1P $_{394-428}$ & PPPVIKFNRPFLMWIVERDTRSILFMGKIVNPKAP & 4106.28 & +4 & $45 \%$ & 35 \\
LL-37 & LLGDFFRKSKEKIGKEFKRIVQRIKDFLRNLVPRTES & 4493.33 & +6 & $35 \%$ & 37 \\
\hline
\end{tabular}


Table 2 Antimicrobial assay bacterial reduction rate equations used to determine CFU after incubation with peptide

\begin{tabular}{ll}
\hline Bacterial strain & Reduction rate equation \\
\hline P. aeruginosa PAO1 & $\log \left(\mathrm{CFU}_{\text {P.aeruginosa }}\right)=\left(\mathrm{T}_{20000}-60948\right) /-5823.3$ \\
E. coli ATCC 51659 & $\log \left(\mathrm{CFU}_{E . \text { coli }}\right)=\left(\mathrm{T}_{20000}-37673\right) /-4292.9$ \\
S. aureus ATCC 33592 & $\log \left(\mathrm{CFU}_{S \text {. aureus }}\right)=\left(\mathrm{T}_{20000}-59514\right) /-7912.2$ \\
A. baumannii & $\log \left(\mathrm{CFU}_{\text {A. baumannii }}\right)=\left(\mathrm{T}_{20000}-34042\right) /-4398.1$ \\
ATCC BAA-1794 & \\
\hline
\end{tabular}

centrifuged at $1000 \mathrm{rpm}$ for $2 \mathrm{~min}$. The supernatant was transferred to a fresh plate and read at $\mathrm{OD}_{540}$ [31].

Cytotoxicity assays were performed using the Vybrant MTT Cell Proliferation Assay Kit (Life Technologies) according to manufacturer's instructions. Assays were performed using human lung epithelial lung carcinoma line A549 (ATCC CCL-185), which were maintained at a low passage in Dulbecco's Minimal Essential Media (Life Technologies 11995073) with $10 \%$ heat-inactivated fetal bovine serum and $13 \mathrm{U} / \mathrm{ml}$ penicillin-streptomycin. 1$100 \mu \mathrm{g} / \mathrm{ml}$ of peptide was used for each experimental well. Each experiment was performed in triplicate two times. A representative experiment is shown.

\section{Statistics}

Statistical analyses were performed using GraphPad Prism 6.0. To determine statistical significance, the oneway ANOVA with Tukey's multiple comparisons was performed in all instances.

\section{Results}

\section{Bioinformatics}

The native, plasma-derived peptide sequences from the de novo sequencing [8] were used to predict the secondary structure and placement within the parent proteins. Apo5 and Apo6 are both part of the C-terminus of an apolipoprotein, apolipoprotein C-1. Apo5 comprises amino acids (aa) 64-86, while Apo6 is the smaller fragment (aa 67-86, shown in Fig. 1a). Both peptides have a +4 charge and a hydrophobic ratio of just over $30 \%$ as determined using APD2 [16]. Apo5 is cleaved at a GluPhe site and Apo6 at a Thr-Lys site. In the full apolipoprotein, both cleavages sites are located in a disordered hinge preceding a $\mathrm{C}$-terminal alpha helix as seen in Fig. 1c.

A1P is also the cleaved C-terminus of its parent protein, a serpin proteinase inhibitor (aa 394-428, shown in Fig. 1b). It carries a +4 charge and a $45 \%$ hydrophobicity ratio. The peptide is cleaved from the parent protein at Asp-Pro site in a disordered region on the exterior of the folded protein, as shown in Fig. 1d. The cleaved peptide itself consists of the two $\beta$-sheet regions that run through the interior of the proteinase.

\section{Secondary structure determination}

To determine general secondary structure of Apo5, Apo6, and A1P, CD spectroscopy was used. CD was performed in $10 \mathrm{mM}$ phosphate buffer, $60 \mathrm{mM}$ SDS, and $50 \%$ TFE in phosphate buffer. Many CAMPs, such as
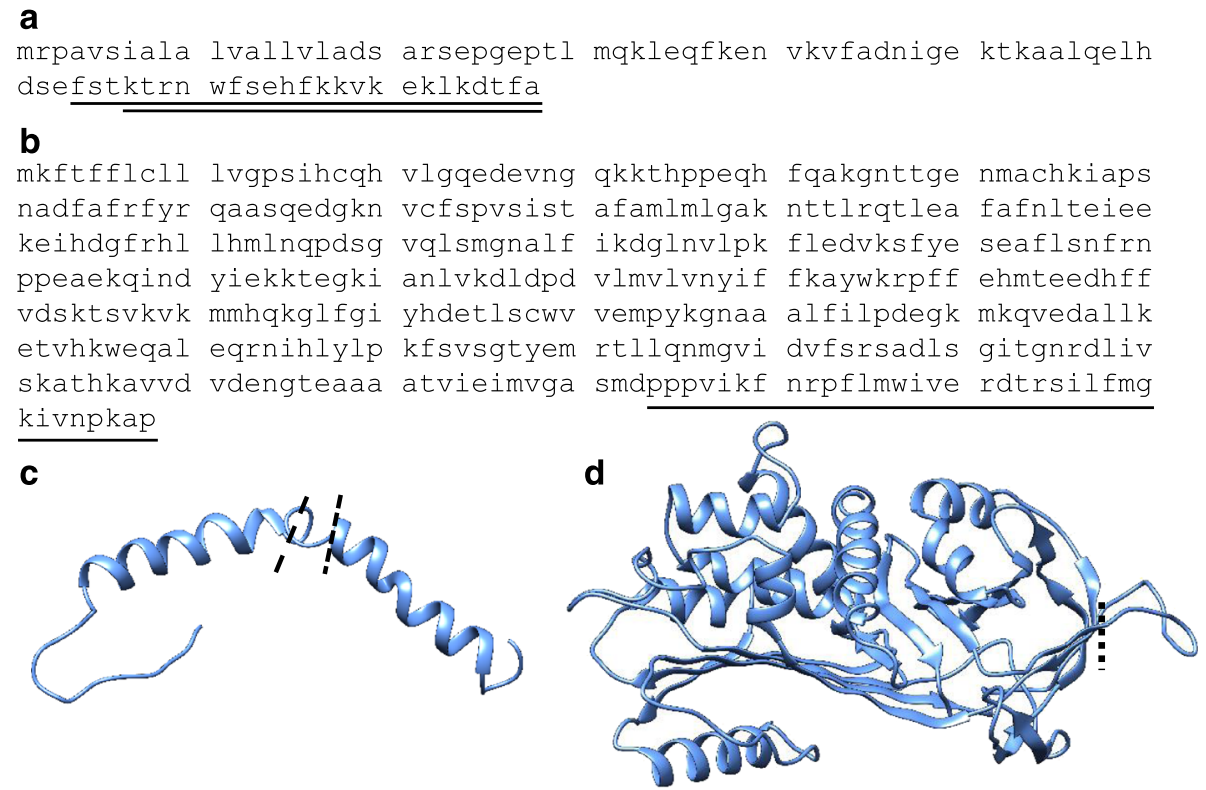

Fig. 1 Primary and tertiary structure of parental proteins and peptide placement within. a Amino acid sequence of A. mississippiensis apolipoprotein C-1 and the Apo5 and Apo6 fragments. b Amino acid sequence of A. mississippiensis alpha-1-proteinase 2-like protein and the A1P fragment. c Ribbon model of apolipoprotein C-1 showing cleavages points of Apo5 (Iong dashes) and Apo6 (short dashes). d Ribbon model of alpha-1-proteinase showing cleavage point of A1P 
LL-37, maintain a random or disordered structure until associated with a membrane or micelle. SDS forms micelles with a negatively charged surface [32], mimicking the bacterial membrane and forcing the CAMP into a more ordered conformation [33, 34].

TFE is used in CD to promote a helical structure [35] and stabilize secondary structure [36].

As expected, Apo5 (Fig. 2a) and Apo6 (Fig. 2b) had nearly identical $\mathrm{CD}$ spectra. Both peptides have random

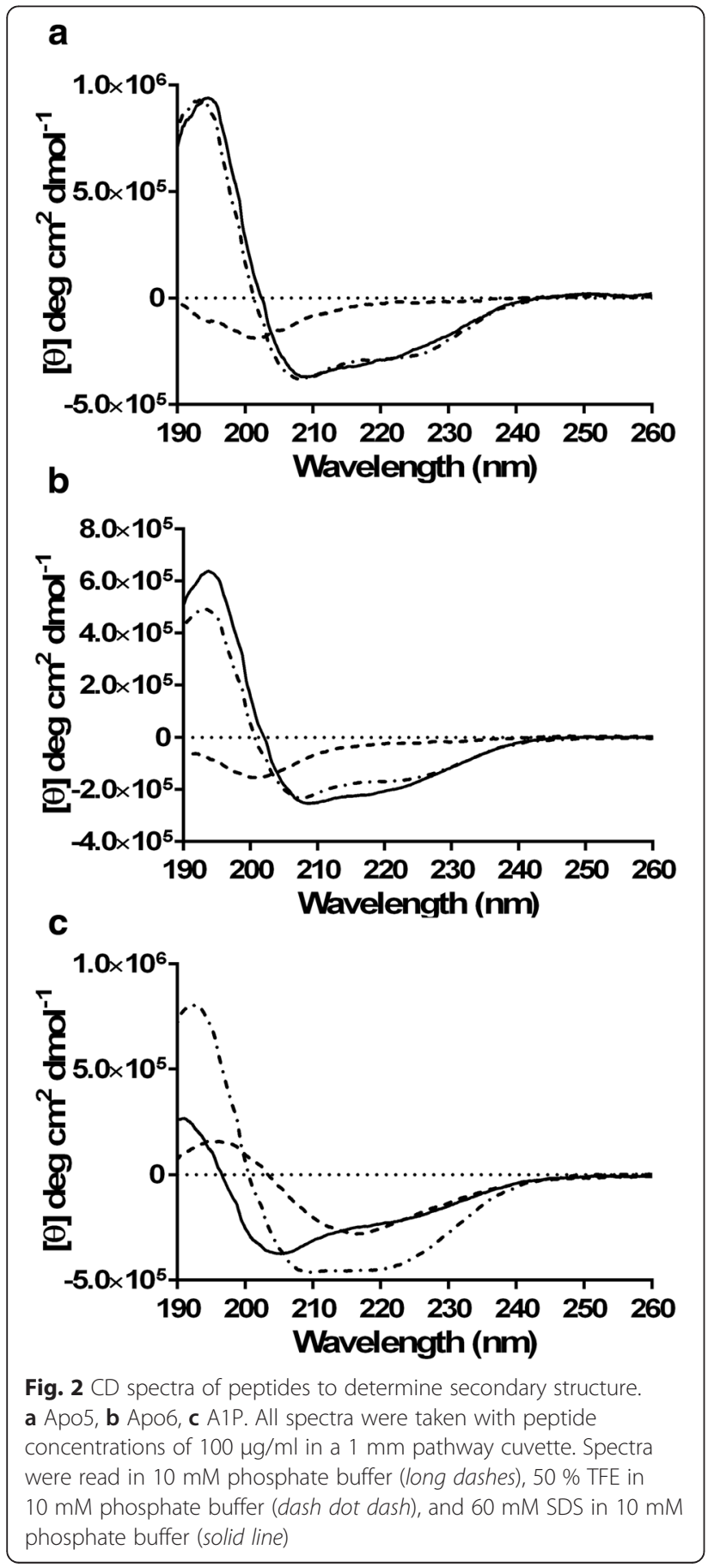

coil and $\beta$-sheet characteristics in $10 \mathrm{mM}$ phosphate buffer, and are primarily $\alpha$-helical when CD is measured in buffers with SDS and TFE. Interestingly, Apo5, the longer of the two peptides, is calculated to have more $\alpha$ helical character than Apo6 in both SDS (63.3 \% vs. $57.0 \%$ ) and TFE (51.0 \% vs. $50.3 \%$ ), shown in Table 3. When evaluating the $\alpha$-helical properties of these two peptides by simple intensity at $208 \mathrm{~nm}$ and $222 \mathrm{~nm}$, it is notable that the peaks at these wavelengths are more intense for Apo5 than Apo6, though the two Apo peptides maintain $12.5 \%$ turn no matter the buffer used. Apo5 and Apo6 likely have a primarily $\alpha$-helical structure with some random coil portions. Based on helical wheel projections, it appears that both Apo5 and Apo6 have significant amphipathic character, with several hydrophobic residues on one face and several basic amino acids on the other. The structure of Apo5 and Apo6 were predicted using I-TASSER and the resulting.pdb file was visualized using Chimera, shown in Fig. $3 a$ and b. Consistent with the CD spectra, both are predicted to be $\alpha$-helical structures. Apo5, the longer peptide, has a longer random coil portion at the $\mathrm{N}$-terminus. This is consistent with the predicted structure of the C-terminal portion of the parental protein, apolipoprotein C-1 (Fig. 1c). Because Apo5 and Apo6 are predicted to helical, helical wheels were produced using Heliquest and modified (Fig. 4). Apo5 and Apo6 have a similar hydrophobic moment (0.436 vs 0.484$) ;$ Apo6 likely has a slightly stronger hydrophobic moment due to the loss of polar Ser in the hydrophobic face of the helix. In $10 \mathrm{mM}$ phosphate buffer, TFE, and SDS, A1P has significantly different spectra (Fig. 2c).

In $10 \mathrm{mM}$ phosphate buffer, A1P is calculated to have primarily $\beta$-sheet contributions (57.9\%), as well as some random coil characteristics (34.7\%), shown in Table 3. By our calculations, A1P also has a negative percentage of contribution from the $\alpha$-helix, which may be

Table 3 Percent secondary structure contribution as calculated by a method described by Raussens et al. [27]

\begin{tabular}{llllll}
\hline & a-helical & $\beta$-sheet & Turn & Random & Sum \\
\hline Apo5 & & & & & \\
Phosphate Buffer & 8.9 & 30.3 & 12.5 & 40.6 & 92.3 \\
TFE & 51 & 4.6 & 12.5 & 29.3 & 97.4 \\
SDS & 63.3 & -4.8 & 12.5 & 25.1 & 96.1 \\
Apo6 & & & & & \\
Phosphate Buffer & 9.4 & 30.5 & 12.5 & 41 & 93.4 \\
TFE & 50.3 & 4.8 & 12.5 & 29.7 & 97.3 \\
SDS & 57 & 0.7 & 12.5 & 26.9 & 97.1 \\
A1P & & & & & \\
Phosphate Buffer & -14.4 & 57.9 & 12.4 & 34.7 & 90.6 \\
TFE & 38.2 & 16.3 & 12.5 & 31.2 & 98.2 \\
SDS & 21.6 & 24.2 & 21.5 & 36.9 & 104.2 \\
\hline
\end{tabular}




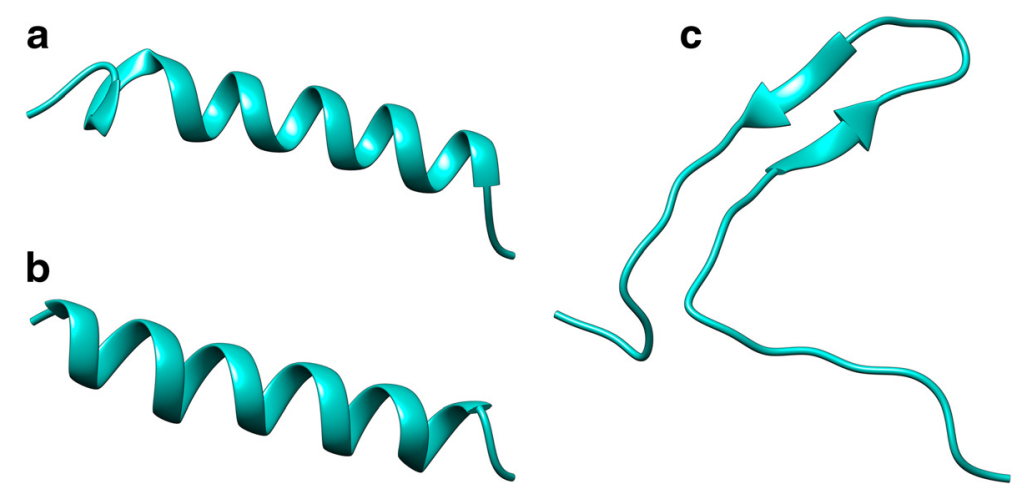

Fig. 3 Secondary structure prediction by L-TASSER [24], visualized by Chimera [25]. a Apo5, b Apo6, c A1P

an artifact of the equations used. In TFE, A1P maintains its random coil nature (31.2 \%), but also becomes strongly $\alpha$-helical (38.2 \%), with only $16.3 \%$ contribution from the $\beta$-sheet. In SDS, A1P is calculated to be nearly equal parts random coil (36.9\%), turn (21.5\%), $\beta$-sheet (24.2\%), and $\alpha$-helix (21.6\%). It has been shown by several groups that TFE can induce and support $\alpha$-helical structures in peptides [37, 38]. By qualitatively evaluating the spectra, we conclude that only in TFE does A1P have a notable $\alpha$-helical structure, though this conformation may be interrupted by several proline residues found along the polypeptide chain. It is likely that A1P has a mixed structure that may change dramatically based on environmental factors. The secondary structure of A1P was predicted by I-TASSER and visualized using Chimera. I-TASSER predicts that A1P is primarily random coil with two anti-parallel $\beta$-sheet in a hairpin formation (Fig. 3c), which corresponds with the structure of the full alpha-1proteinase structure.

\section{Antimicrobial activity}

Previously, we reported that Apo5 and Apo6 had strong broad-spectrum antimicrobial activity against $E$. coli and $B$. cereus, as well as $S$. aureus and $P$. aeruginosa [8]. It was also found that A1P had greater activity against $S$. aureus than $P$. aeruginosa [8], indicating it may have stronger activity against Gram-positive organisms.

Antibiotic resistance has been increasing steadily for the past several decades, and CAMPs are considered a possible basis for novel antimicrobials. Because of this, these new peptides were tested against clinically isolated and multi-drug resistant strains of $S$. aureus, E. coli, $P$. aeruginosa and $A$. baumannii. Numerical and statistical data can be found in Table 4. Sharing a salt-sensitive phenotype with LL-37 [34, 39, 40], these peptides had no effect in MIC experiments as high as $250 \mu \mathrm{g} / \mathrm{ml}$, so experiments were performed to determine the $\mathrm{EC}_{50}$ in $10 \mathrm{mM}$ phosphate buffer. We performed these low-salt experiments using vancomycin as a control for Grampositive bacteria and polymyxin $\mathrm{B}$ as a control for Gram-negative bacteria. Polymyxin B was found to be very effective against all strains tested, with all EC50 values being under $1 \mu \mathrm{g} / \mathrm{ml}$, except against $E$. coli ATCC $4157(2.50 \mu \mathrm{g} / \mathrm{ml})$. In the case of vancomycin, we found that this antibiotic did not kill either $S$. aureus strain under $100 \mu \mathrm{g} / \mathrm{ml}$, though the MIC for both strains was $1 \mu \mathrm{g} / \mathrm{ml}$, indicating that vancomycin is bacteriostatic but not reliably bactericidal.
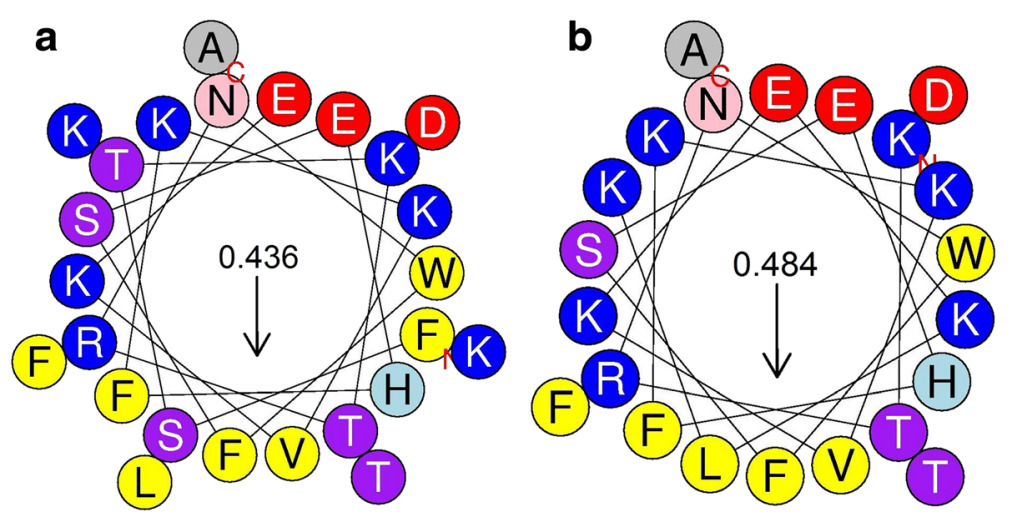

Fig. 4 Helical wheels of a Apo5 and b Apo6, modified from Heliquest 
Table 4 Antimicrobial activity and statistical data

\begin{tabular}{|c|c|c|c|c|c|}
\hline Peptide & Bacteria & $\mathrm{MIC}(\mu \mathrm{g} / \mathrm{ml})$ & EC50 ( $\mu \mathrm{g} / \mathrm{ml})$ & $95 \% \mathrm{Cl}(\mu \mathrm{g} / \mathrm{ml})$ & EC50 $(\mu \mathrm{M})$ \\
\hline \multirow[t]{8}{*}{ Apo5 } & E. coli ATCC 4157 & NT & 19.7 & 13.1 to 29.6 & 6.35 \\
\hline & E. coli ATCC 51659 & $>250$ & 13.9 & 10.7 to 18.0 & 4.48 \\
\hline & S. aureus ATCC BAA-1718 & NT & 4.96 & 2.82 to 8.72 & 1.60 \\
\hline & S. aureus ATCC 33592 & $>250$ & 0.0680 & 0.124 to 0.357 & 0.0219 \\
\hline & P. aeruginosa $\mathrm{PAO} 1$ & $>250$ & 0.0878 & 0.0326 to 0.237 & 0.0283 \\
\hline & P. aeruginosa ATCC BAA-2110 & NT & 0.467 & 0.234 to 0.934 & 0.150 \\
\hline & A. baumannii ATCC 9955 & NT & 0.644 & 0.480 to 0.865 & 0.207 \\
\hline & A. baumannii ATCC BAA-1794 & $>250$ & 0.234 & 0.122 to 0.450 & 0.0755 \\
\hline \multirow[t]{8}{*}{ Apo6 } & E. coli ATCC 4157 & NT & 3.85 & 2.71 to 5.48 & 1.39 \\
\hline & E. coli ATCC 51659 & $>250$ & 9.07 & 7.11 to 11.6 & 3.28 \\
\hline & S. aureus ATCC BAA-1718 & NT & 2.31 & 1.69 to 3.16 & 0.835 \\
\hline & S. aureus ATCC 33592 & $>250$ & 0.883 & 0.526 to 1.48 & 0.319 \\
\hline & P. aeruginosa $\mathrm{PAO} 1$ & $>250$ & 1.17 & 0.866 to 1.62 & 0.429 \\
\hline & P. aeruginosa ATCC BAA-2110 & NT & 0.130 & 0.100 to 0.168 & 0.0470 \\
\hline & A. baumannii ATCC 9955 & NT & 0.233 & 0.129 to 0.419 & 0.0842 \\
\hline & A. baumannii ATCC BAA-1794 & $>250$ & 0.126 & 0.0899 to 0.176 & 0.126 \\
\hline \multirow[t]{8}{*}{ A1P } & E. coli ATCC 4157 & NT & 9.2 & 5.90 to 14.4 & 2.24 \\
\hline & E. coli ATCC 51659 & $>250$ & 2.51 & 1.55 to 4.08 & 0.611 \\
\hline & S. aureus ATCC BAA-1718 & NT & 36.5 & 25.1 to 53.1 & 8.89 \\
\hline & S. aureus ATCC 33592 & $>250$ & 2.68 & 1.51 to 4.76 & 0.653 \\
\hline & P. aeruginosa PAO1 & $>250$ & 38.6 & 4.01 to 372 & 9.4 \\
\hline & P. aeruginosa ATCC BAA-2110 & NT & $>800$ & & $>195$ \\
\hline & A. baumannii ATCC 9955 & NT & 24.0 & 1.52 to 7.19 & 5.84 \\
\hline & A. baumannii ATCC BAA-1794 & $>250$ & 2.36 & 0.370 to 1.75 & 0.575 \\
\hline \multirow[t]{8}{*}{ LL-37 } & E. coli ATCC 4157 & NT & 0.191 & 0.109 to 0.337 & 0.0425 \\
\hline & E. coli ATCC 51659 & $>250$ & 0.298 & 0.208 to 0.428 & 0.0663 \\
\hline & S. aureus ATCC BAA-1718 & NT & 0.839 & 0.497 to 1.42 & 0.187 \\
\hline & S. aureus ATCC 33592 & $>250$ & 0.208 & 0.138 to 0.312 & 0.0462 \\
\hline & P. aeruginosa $\mathrm{PAO} 1$ & $>250$ & 0.647 & 0.598 to 6.96 & 0.144 \\
\hline & P. aeruginosa ATCC BAA-2110 & NT & 2.26 & 1.50 to 3.41 & 0.503 \\
\hline & A. baumannii ATCC 9955 & NT & 1.46 & 1.04 to 2.07 & 0.825 \\
\hline & A. baumannii ATCC BAA-1794 & $>250$ & 0.804 & 0.370 to 1.75 & 0.179 \\
\hline \multirow[t]{6}{*}{ Polymyxin B } & E. coli ATCC 4157 & NT & 2.50 & 0.831 to 7.50 & 1.92 \\
\hline & E. coli ATCC 51659 & NT & 0.00181 & 0.00135 to 0.00244 & 0.00139 \\
\hline & P. aeruginosa PAO1 & NT & 0.00568 & 0.00458 to 0.00704 & 0.00436 \\
\hline & P. aeruginosa ATCC BAA-2110 & NT & 0.0109 & 0.00706 to 0.0157 & 0.00837 \\
\hline & A. baumannii ATCC 9955 & NT & 0.121 & 0.0895 to 0.164 & 0.0013 \\
\hline & A. baumannii ATCC BAA-1794 & NT & 0.0131 & 0.0111 to 0.0153 & 0.0101 \\
\hline \multirow[t]{2}{*}{ Vancomycin } & S. aureus ATCC BAA-1718 & 1 & $>100$ & & $>69.0$ \\
\hline & S. aureus ATCC 33592 & 1 & $>100$ & & $>69.0$ \\
\hline
\end{tabular}

MIC is determined in Mueller Hinton Broth II. EC50 is determined in $10 \mathrm{mM}$ sodium phosphate buffer. NT Not Tested

In general, it was found that the $\mathrm{EC}_{50}$ values of $\mathrm{Apo} 5$ and Apo6 were statistically similar and showed broadspectrum activity. We found that both apolipoprotein- derived peptides had strong activity against a clinical isolate of $S$. aureus ATCC BAA-1718 $\left(\mathrm{EC}_{50}<5 \mu \mathrm{g} / \mathrm{ml}\right)$. Both Apo5 and Apo6 were found to have very strong 
activity $\left(\mathrm{EC}_{50}<1 \mu \mathrm{g} / \mathrm{ml}\right)$ against drug sensitive and MDR A. baumannii (ATCC BAA-1794), MRSA (ATCC 33592), and MDR P. aeruginosa (ATCC BAA-2110). It was also found that Apo5 and Apo6 were somewhat less active against both strains of $E$. coli tested, with $\mathrm{EC}_{50}$ values ranging from 4 to $20 \mu \mathrm{g} / \mathrm{ml}$, though our previous work demonstrated that these peptides were extremely effective against E. coli ATCC 25922 [8]. Apo5 and Apo6 had differing activities against $P$. aeruginosa PAO1; Apo5 was found to have stronger activity against this strain than Apo6 $(0.0878 \mu \mathrm{g} / \mathrm{ml}$ vs $1.17 \mu \mathrm{g} / \mathrm{ml})$.

A1P was found to have stronger broad-spectrum activity than anticipated from our previous study [8]. Although A1P had weak activity against $P$. aeruginosa PAO1 $\left(\mathrm{EC}_{50}=38.6 \mu \mathrm{g} / \mathrm{ml}\right)$, it was not effective at concentrations tested against MDR $P$. aeruginosa (ATCC BAA-2110) (Table 4). A1P had stronger antimicrobial activity against MDR strains of E. coli (ATCC 51659), $S$. aureus (ATCC 33592), and A. baumannii (ATCC BAA1794), with $\mathrm{EC}_{50}$ values between 2 and $3 \mu \mathrm{g} / \mathrm{ml}$, than against the antibiotic sensitive strains tested, which had $\mathrm{EC}_{50}$ values ranging from 9 to $36 \mu \mathrm{g} / \mathrm{ml}$.

\section{Membrane permeabilization and depolarization by peptides}

To determine whether Apo5, Apo6, and A1P interacted with the bacterial membrane, each peptide's ability to disrupt or permeabilize the membrane was measured by the ethidium bromide uptake assay, while membrane depolarization was measured with the fluorescent chemical $\mathrm{DiSC}_{3}(5)$, which is sensitive to the polarization of membranes.

When the ethidium bromide uptake assay was performed (Fig. 5a), it was found that Apo5 and Apo6 permeabilized the $E$. coli membrane at concentrations at $50 \mu \mathrm{g} / \mathrm{ml}$ quickly, comparable to control peptide LL-37, a known pore-forming peptide. Neither Apo peptide permeabilized membranes at lower concentrations. Like LL-37, these peptides permeabilized the membrane in a significant manner $(p<0.001)$, with peak fluorescence occurring within $3 \mathrm{~min}$. A1P also permeabilized the membrane at $50 \mu \mathrm{g} / \mathrm{ml}$ significantly higher than the untreated control $(p<0.001)$, but displayed very different and slower kinetics. With this peptide, fluorescence gradually increased over the 20 min experimental time frame, until reaching nearly equivalent maximum fluorescence as Apo5 and Apo6 by the end of the experiment (Fig. 5b).

Depolarization of a bacterial membrane indicates transient membrane disruption that allows for ion leakage, which damages the proton motive force and other gradients that store chemical energy. As shown in Fig. 6, within 1 min it was found that Apo5 and Apo6 depolarized bacterial membranes at concentrations as low as

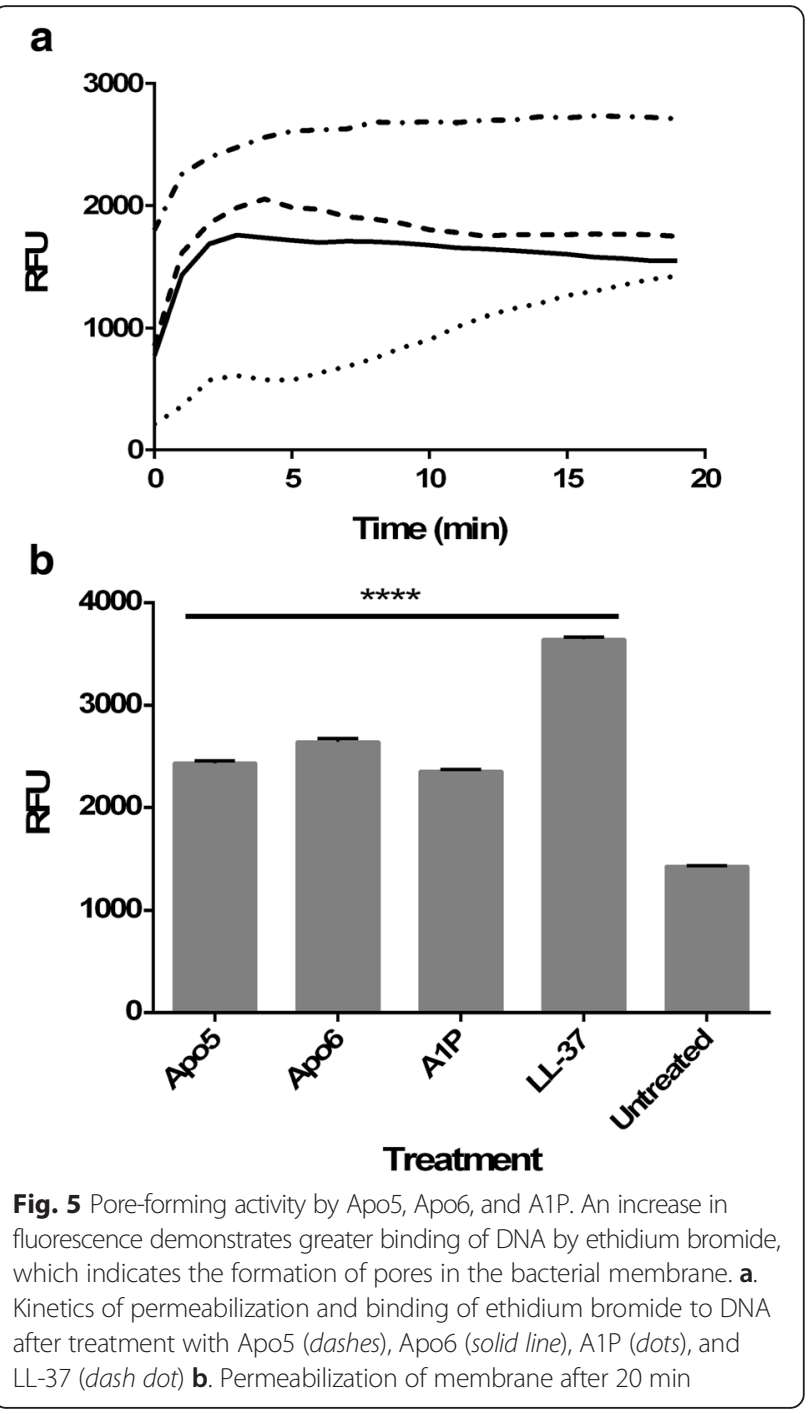

$0.5 \mu \mathrm{g} / \mathrm{ml}(\mathrm{p}<0.001)$, with depolarization showing a clear dose-dependent response to peptide concentration. A1P did not depolarize membranes except at the highest concentration tested, $50 \mu \mathrm{g} / \mathrm{ml}(p<0.05)$. Depolarization signals at this concentration were well below those achieved at the lowest concentrations used for Apo5, Apo6, and LL-37 $(p<0.001)$.

These results indicate that Apo5 and Apo6 depolarize the bacterial membrane quickly, suggesting membrane disruption is the mechanism by which these peptides kill bacteria. A1P does not depolarize the membrane, nor does it form pores quickly except at high concentrations. This implies that the primary mechanism of A1P is not related to membrane disruption.

\section{DNA binding}

Some peptides, such as LL-37 or histone-derived Buforin II, bind nucleic acids [4, 41], inhibiting translation and transcription or promoting mutagenesis. In general, this 


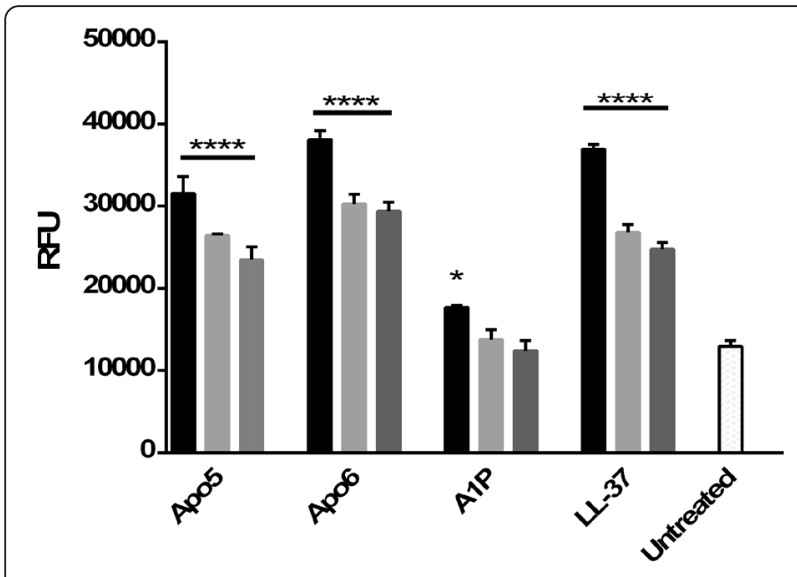

Treatment

Fig. 6 Membrane depolarization activity by Apo5, Apo6, and A1P. Depolarization determined using $\mathrm{DiSC}_{3}(5)$ for each peptide at $50 \mu \mathrm{g} / \mathrm{ml}(\mathbf{-}), 5 \mu \mathrm{g} / \mathrm{ml}($ ), $0.5 \mu \mathrm{g} / \mathrm{ml}($ ), as well as no treatment (

binding mechanism has been shown to be non-specific $[41,42]$. To determine if any of the CAMPs were able to bind DNA, a gel shift assay was performed, shown in Fig. 7. A1P bound DNA only at very high ratios, needing at least 20 times more mass of peptide than DNA to inhibit DNA movement. Apo6 did not bind DNA at any concentration, while Apo5 bound DNA only at the highest concentration tested. It is unlikely that the primary mechanism of action of these three peptides is related to DNA binding.

\section{Cytotoxicity}

The physiochemical properties of CAMPs preclude significant host-cell cytotoxicity; however, some CAMPs, such as SMAP-29, have been found to cause damage to eukaryotic cells at similar concentrations. Cytotoxicity against red blood cells and A549 lung epithelial cells was measured. For red blood cells, a spectrophotometric assay that measures free heme was used, while an MTT assay was used for A549 cells. As shown in Table 4, these peptides have EC50's between 0.07-39 $\mu \mathrm{g} / \mathrm{ml}$. In Fig. 8a, hemolytic activity is shown as percent hemolysis. All four peptides showed hemolysis of RBCs of less than $1 \%$ at $300 \mu \mathrm{g} / \mathrm{ml}$, a, comparable to the control peptide LL-37. No statistically significant difference was found between the untreated control and all peptides, indicating that Apo5, Apo6, and A1P are not hemolytic. The MTT assay was used to measure cytotoxicity of other cells lines. After $24 \mathrm{~h}$ exposure, concentrations of peptide up to $100 \mu \mathrm{g} / \mathrm{ml}$ were not significantly cytotoxic against A549 cells, as shown in Fig. 8b, while the EC50 against $A$. baumannii was less than $1 \mu \mathrm{g} / \mathrm{ml}$ of Apo peptide.

\section{Discussion}

Using our CAMP discovery process and only $100 \mu \mathrm{l}$ of alligator plasma, we have previously identified five novel antimicrobial peptides from $A$. mississippiensis that exhibit antibacterial activity [8]. Our bioprospecting-based process provides a unique access to the antimicrobial peptidome, and is a significant advance in the effort to identify novel antimicrobial peptides in nature. In this study, we present detailed characterization of the structure and function of three alligator plasma-derived peptides: Apo5, Apo6, and A1P. We demonstrated that Apo5, Apo6, and A1P are potent antimicrobial peptides that extend their efficacy against multi-drug resistant and clinically relevant pathogens, such as A. baumannii.

The two peptides Apo5 and Apo6 are both derived from a predicted apolipoprotein $\mathrm{C}-1$ in A. mississippiensis. Apolipoproteins bind lipids; apolipoprotein $\mathrm{C}-1$ in particular is known to bind phospholipids and is a marker of apoptosis [11, 12, 43, 44]. Apo6 is a smaller derivative of Apo5; Apo5 contains residues 64-88 of predicted apolipoprotein $\mathrm{C}-1$, while Apo6 contains residues 67-88. These peptides were very active against Gramnegative bacteria. Previously, Apo5 and Apo6 were each found to be strongly active against E. coli ATCC 25922 and $P$. aeruginosa ATCC 9027 while $\mathrm{EC}_{50}$ values were much higher for virulent Staphylococcus aureus (ATCC 25923). We discovered that Apo5 and Apo6 are predominantly helical peptides. Their mode of antibacterial

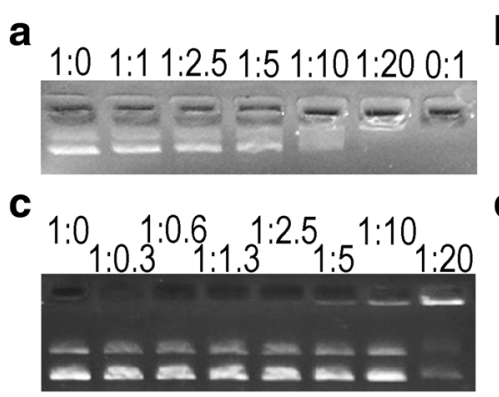

b

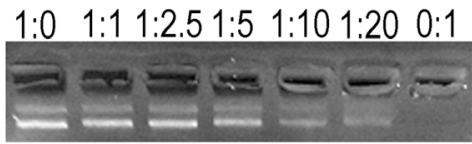

d

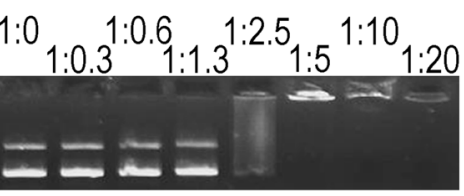

Fig. 7 DNA binding by a Apo5, b Apo6, c A1P, and $\mathbf{d} L L-37$ as measured using a gel shift assay. Ratio of DNA:CAMP is shown 


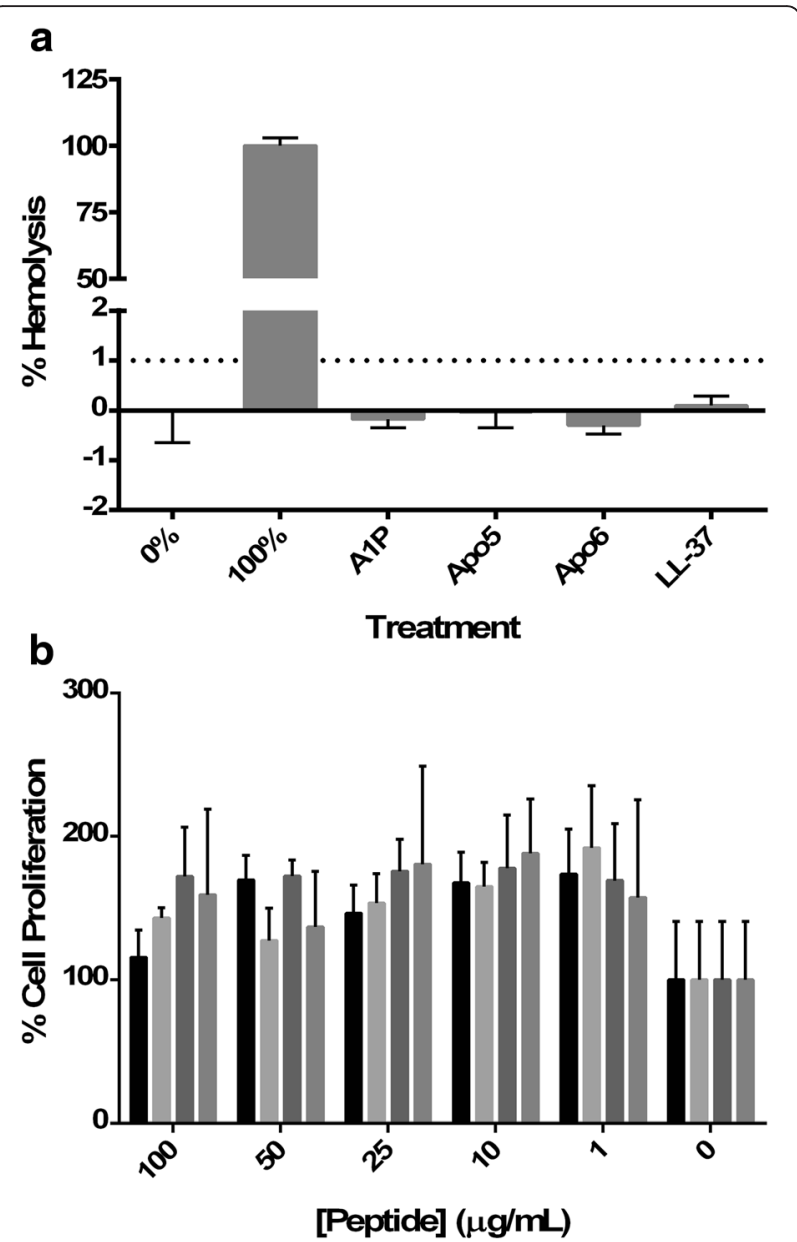

Fig. 8 Peptide Cytotoxicity a. Hemolysis of sheep red blood cells was measured using a photometric assay after exposure to $300 \mathrm{\mu g} / \mathrm{ml}$ for $1 \mathrm{~h}$ and $\mathbf{b}$. Inhibition of Proliferation of A549 human lung epithelial cells measured using the MTT assay after $24 \mathrm{~h}$ exposure. Apo5 ((口), Apo6 ( ) , A1P ( ) , LL-37 ( )

activity appears to be primarily through membrane interaction. At low concentrations (approximately the $\mathrm{EC}_{50}$ for all bacteria), Apo5 and Apo6 depolarized the membrane of $E$. coli. At high concentrations, well above the $\mathrm{EC}_{50}$ for all bacteria tested, these peptides more strongly disrupted the bacterial membrane, possibly via pore formation, allowing for the escape of large cellular milieu. Based on these observations, it seems that the primary mode of action of these apolipoprotein-derived peptides is membrane perturbation and depolarization.

The antimicrobial activity of apolipoproteins has been highlighted in other organisms, although typically apolipoprotein A is studied [9-12, 14, 45]. Many whole apolipoproteins have been found to have antimicrobial activity against a variety of bacteria, as well as some viruses. Apolipoprotein A-1 from various fishes have been shown to have antimicrobial activity against $E$. coli [11, 12, 46], Streptococcus spp. [11] and fish pathogens such as Mycobacterium marinum [11] and Yersinia ruckeri [12]. The antimicrobial activity of human apolipoprotein A-1 has also been examined, and several groups have found that this protein is effective against E. coli, Klebsiella pneumoniae, and Yersinia enterocolitica $[10,44]$. The primary mode of action of apolipoprotein A-1 seems to be as a detergent; it has been shown to bind lipids including LPS and to dissolve micelles [12, 44, 47]. The LPS-binding activity in particular has been shown to be reliant on the $\mathrm{N}$ terminus of the protein [44]. The mechanism of action and antimicrobial activity of apolipoprotein C1 has not yet been explored, but it likely binds lipids as some part of its mechanism.

Apo5 and Apo6 were not found to bind E. coli LPS as part of its mechanism (data not shown), but these two peptides are located on the C-terminus of apolipoprotein C-1. To our knowledge, fragments of apolipoproteins have not been characterized prior to this work. Other groups have studied synthetic mimetics of apolipoprotein $\mathrm{E}$, which have been found to have anti-infective effects against HIV-1 and HSV-1 [48] and antimicrobial activity against MDR bacteria [14]. This characterization of the broad antimicrobial activity of apolipoprotein C1-derived peptides in the present work adds to the understanding of this family of CAMPs.

A1P is a fragment of a predicted alpha-1-proteinase. A1P contains amino acids 394-428 of this proteinase inhibitor. Though the primary role of alpha-1-proteinase is the inhibition of human neutrophil elastase, it also inhibits a number of other proteases, such as proteinase 3 [49], some kallikreins [50], matriptase [51], and caspase3 [52]. It has also been shown to have an important role in immune modulation. Alpha-1-proteinase is an acutephase reactant; levels of this protein increase 3 to 4 fold in response to PAMPs or inflammation $[53,54]$. Alpha-1proteinase is involved in neutrophil degranulation [55]. It has also been shown to protect mice from LPS- and TNFassociated lethality, possibly by preventing the release of membrane-bound TNF [56]. Alpha-1-proteinase also interacts with human neutrophil peptides to reduce their cytotoxic affects towards lung cells; this has been demonstrated in vitro and in vivo [57].

This protein may play a role in the disease progression of some bacteria such as Francisella tularensis. Studies have shown that alpha-1-proteinase is decreased during a pulmonary $F$. tularensis challenge in mice. This could lead to unchecked neutrophil elastase activity, which damages the alveoli and lung tissue, allowing bacteria to quickly disseminate through the body and to the liver [58]. Though other protease inhibitors have been shown to have antimicrobial activity, previously $\alpha$-1-proteinase and its fragments had only been shown to have antiinfective activity, not direct antimicrobial activity. The 
whole protein has shown to have protective activity against $P$. aeruginosa, by suppressing bacterial proliferation and tissue inflammation $[59,60]$. Whole alpha-1proteinase, as well as a fragment and cyclic derivatives, have demonstrated the ability to prevent HIV-1 infection, possibly by inhibiting production of the virus [61-63]. Interestingly, this anti-HIV-1 fragment is the C-terminal fragment of the protein, where A1P is also found. The antibacterial mechanism of action is not yet clear from the scope of this study. A1P was not found to depolarize the bacterial membrane or form larger pores except at concentrations much higher than calculated $\mathrm{EC}_{50}$ values. $\mathrm{A} 1 \mathrm{P}$ was also not found to bind DNA effectively. However, considering that A1P does interact with the membrane and form pores in high concentrations slowly, as discussed in section 3.4, it is possible that A1P crosses the bacterial membrane and interacts with a non-nucleic acid target or inhibits bacterial proteases that are necessary for viability. It seems possible that the anti-HIV-1 function described by other groups is the same function that kills bacteria.

Vancomycin and polymyxin B are drugs of last resort in the treatment of extremely multi-drug-resistant bacteria, and yet resistance to even these two drugs is currently rising [64-66]. In addition, both vancomycin and polymyxin $\mathrm{B}$ are known to be hemolytic and cytotoxic to some cell lines $[67,68]$. It is clear that new antimicrobials are needed, particularly drugs with low cytotoxicity. LL-37 is a well-studied peptide with broadspectrum activity. In this study, we have used LL-37 as a peptide control. We found that the alligator CAMPs tested had comparable activity to LL-37 against some species. LL-37 was found to have very strong activity against all species tested, with $\mathrm{EC}_{50}$ values all below $3 \mu \mathrm{g} / \mathrm{ml}$. Apo5 and Apo6 had comparable activity against strains of $P$. aeruginosa, A. baumannii, and MRSA (ATCC 33592), but were less active against strains of $E$. coli tested, with $\mathrm{EC}_{50}$ values ranging from $2-20 \mu \mathrm{g} / \mathrm{ml}$. These peptides also had similar membrane perturbation activity as LL-37, with membrane depolarization at low concentrations and pore formation and disruption at very high concentrations. A1P had weaker activity than LL-37 against susceptible strains of bacteria tested $\left(\mathrm{EC}_{50}\right.$ values between 9 and $40 \mu \mathrm{g} / \mathrm{ml}$ ) but stronger and comparable activity to LL-37 against drug-resistant strains of E. coli, S. aureus, and A. baumannii, with $\mathrm{EC}_{50}$ values less than $3 \mu \mathrm{g} / \mathrm{ml}$. Interestingly, A1P was not active against drug-resistant $P$. aeruginosa. We performed experiments with ethidium bromide and $\operatorname{Disc}_{3}(5)$ using A1P against both strains of $P$. aeruginosa at $40 \mu \mathrm{g} / \mathrm{ml}$, the approximate $\mathrm{EC}_{50}$ of $\mathrm{A} 1 \mathrm{P}$ against $P$. aeruginosa $\mathrm{PAO}$, to determine if this difference in activity was due to differences in membrane interaction (data not shown). However, there was no difference in either depolarization or disruption. In our previous work, we found that A1P was least effective against $P$. aeruginosa ATCC 9027 in a panel also including other strains of S. aureus, E. coli, and Bacillus cereus [8]. It is possible that $P$. aeruginosa is intrinsically resistant to this particular peptide.

The novel CAMPs characterized here are among the first discovered using our hydrogel bioprospecting technology, illustrating the power of this technology to capture naturally occurring small peptides with net cationic charge and antimicrobial activity [8]. Considering the strong and broad-spectrum activity of these CAMPs, it seems likely that there is a greater role for protein fragments in peptide-based innate immunity than previously thought. Apolipoproteins are a highly conserved class of proteins, and it is very likely that fragments are produced in similar patterns across species. For example, though the human apolipoprotein C-I (accession AAH55093) shares $41 \%$ identity with the American alligator version, the Cterminal 25 aa on each protein, where Apo5 is found, shares $59 \%$ identity. This theoretical fragment of the human apolipoprotein C-I, with the sequence ELSAKMR EWFSETFQKVKEKLKIDS, is also predicted to be helical, with a weaker hydrophobic moment $(0.375 \mu \mathrm{H})$ and similar hydrophobicity (36 \%), but is less charged the alligator Apo5 (+1), according to Heliquest [26] and The Antimicrobial Peptide Database [16]. The human peptide is not predicted to be antimicrobial by CAMPR3, but neither is Apo5, and we have discussed previously the weaknesses of commonly used antimicrobial peptide predictors [8]. We are currently working to determine whether some of these fragmentation patterns are conserved across species.

In addition, these CAMPs are more effective against drug-resistant strains than normal laboratory strains, indicating these CAMPs may be valuable basis for treatments against multi-drug resistant bacteria. Considering the strength of Apo5 and Apo6 on MDR A. baumannii in particular and the low cytotoxicity of these peptides, these are strong candidates for in vivo testing, or to use as scaffolds for stronger synthetic CAMPs.

\section{Conclusion}

Apo5, Apo6 and A1P are antimicrobial peptides found the plasma of the American alligator. Apo5 and Apo6 are alpha-helical C-terminal fragments of apolipoprotein $\mathrm{C}-1$. These peptides have strong activity against $S$. aureus and a number of Gram-negative bacteria, including MDR A. baumannii and P. aeruginosa. Apo5 and Apo6 primarily work by depolarizing the bacterial membrane. A1P is a C-terminal fragment of the alligator alpha-1proteinase. It has strong activity against $S$. aureus and a number of Gram-negative bacteria, but not MDR P. aeruginosa. A1P has a mixed structure, and the mechanism of action was not clear based on experiments performed; however, it does seem to slowly disrupt the bacterial membrane. 
These peptides are fragments of conserved proteins found in many animals, indicating that these peptides could play a role in immune response of many animals. In addition, new antimicrobials are desperately needed against MDR Gram-negative bacteria. Apo5 and Apo6 in particular have strong activity against MDR pathogens of clinical interest, and the native peptides or synthetic variations will make strong candidates for in vivo testing and pre-clinical trials.

\section{Abbreviations}

ATCC, American type culture collection; BLAST, basic local alignment search tool; BSA, bovine serum albumin; CAMP, cationic antimicrobial peptide; $C D$, circular dichroism; Cl, 95 \% confidence intervals; DiSC3(5), 3,3'dipropylthiadicarbocyanine iodide; DTT, dithiothreitol; EC50, half maximal effective concentration; EDTA, ethylenediaminetetraacetic acid; ESI-MS, electrospray ionization mass spectrometry; Fmoc, fluorenylmethyloxycarbonyl; HIV, human immunodeficiency virus; HPLC, high performance liquid chromatography; LPS, lipopolysaccharide; MDR, multi-drug resistant; MTT, 3-(4,5-Dimethylthiazol-2-yl)-2,5-diphenyltetrazolium bromide; NCBI, National Center for Biotechnology Information; OD, optical density; PAMP, pathogen-associated molecular pattern; PBS, phosphate buffered saline; RBC, red blood cell; RFU, relative fluorescence units; SDS, sodium dodecyl sulfate; TFE, trifluoroethanol; TNF, tumor necrosis factor

\section{Acknowledgements}

We thank Dr. Barney Bishop for continued collaboration and Dr. Joel Schnur and the "peptide team" for support and helpful discussions. Many thanks to Robert Ulrey and Dr. Kajal Gupta for technical assistance and to Dr. K. Sauer (Binghamton University) for PA01.

\section{Funding}

SMB, EJH, EMCC and MVH are supported by HDTRA1-12-C-0039 "Translational Peptide Research for Personnel Protection." Circular dichroism was performed on a CD instrument purchased with funds from the same grant (HDTRA1-12C-0039). The funding body played no role in the design of the study, the collection, analysis, and interpretation of data, and in writing the manuscript.

\section{Availability of data and material}

The datasets during and/or analysed during the current study available from the corresponding author on reasonable request.

\section{Authors' contributions \\ SMB performed antimicrobial assays, ethidium bromide uptake assays, membrane depolarization assays, CD spectroscopy, bioinformatics, and statistical analysis and drafted the manuscript. EJH performed hemolysis and cytotoxicity studies and antimicrobial assays. EMCC performed gel shift assays and assisted with ethidium bromide uptake assays and membrane depolarization assays. MVH developed the study and its design and helped draft the manuscript. All authors read and approved the final manuscript.}

\section{Competing interests}

The authors declare they have no competing interests.

\section{Consent for publication}

Not applicable.

\section{Ethics approval and consent to participate}

Not applicable.

\section{Author details}

'School of Systems Biology, George Mason University, Manassas, VA, USA. ${ }^{2}$ College of Science, George Mason University, Manassas, VA, USA. ${ }^{3}$ National Center of Biodefense and Infectious Diseases, George Mason University, 10920 George Mason Cir, 10920 George Mason Circle, MSN 1H8, Manassas, VA 20110, USA. ${ }^{4}$ Present Address: STCube Pharmaceuticals, Inc., 401 Professional Dr. Suite 108, Gaithersburg, MD 20879-3429, USA.
Received: 1 June 2016 Accepted: 4 August 2016

Published online: 19 August 2016

\section{References}

1. Nakatsuji T, Gallo RL. Antimicrobial peptides: old molecules with new ideas. $J$ Invest Dermatol. 2012;132(3 Pt 2):887-95.

2. van Hoek M. Antimicrobial peptides in reptiles. Pharmaceuticals. 2014;7(6):723.

3. Juba ML, Porter DK, Williams EH, Rodriguez CA, Barksdale SM, Bishop BM. Helical cationic antimicrobial peptide length and its impact on membrane disruption. Biochim Biophys Acta Biomembr. 2015;1848(5):1081-91.

4. Park CB, Kim HS, Kim SC. Mechanism of action of the Antimicrobial Peptide Buforin II: Buforin II kills microorganisms by penetrating the cell membrane and inhibiting cellular functions. Biochem Biophys Res Commun. 1998:244(1):253-7.

5. Chung MC, Dean $\mathrm{SN}$, van Hoek ML. Acyl carrier protein is a bacterial cytoplasmic target of cationic antimicrobial peptide LL-37. Biochem J. 2015;470(2):243-53.

6. Preecharram $S$, Jearranaiprepame $P$, Daduang $S$, Temsiripong $Y$, Somdee $T$, Fukamizo T, Svasti J, Araki T, Thammasirirak S. Isolation and characterisation of crocosin, an antibacterial compound from crocodile (Crocodylus siamensis) plasma. Anim Sci J. 2010;81(3):393-401.

7. Merchant ME, Leger N, Jerkins E, Mills K, Pallansch MB, Paulman RL, Ptak RG. Broad spectrum antimicrobial activity of leukocyte extracts from the American alligator (Alligator mississippiensis). Vet Immunol Immunopathol. 2006;110(3-4):221-8

8. Bishop BM, Juba ML, Devine MC, Barksdale SM, Rodriguez CA, Chung MC, Russo PS, Vliet KA, Schnur JM, van Hoek ML. Bioprospecting the American Alligator (Alligator mississippiensis) host defense peptidome. PLoS One. 2015;10(2):e0117394

9. Pridgeon JW, Klesius PH. Apolipoprotein A1 in channel catfish: transcriptional analysis, antimicrobial activity, and efficacy as plasmid DNA immunostimulant against Aeromonas hydrophila infection. Fish Shellfish Immunol. 2013;35(4):1129-37.

10. Biedzka-Sarek M, Metso J, Kateifides A, Meri T, Jokiranta TS, Muszyński A, Radziejewska-Lebrecht J, Zannis V, Skurnik M, Jauhiainen M. Apolipoprotein A-l exerts bactericidal activity against Yersinia enterocolitica Serotype 0:3. J Biol Chem. 2011;286(44):38211-9.

11. Johnston LD, Brown G, Gauthier D, Reece K, Kator H, Van Veld P. Apolipoprotein A-I from striped bass (Morone saxatilis) demonstrates antibacterial activity in vitro. Comp Biochem Physiol B Biochem Mol Biol. 2008;151(2):167-75.

12. Villarroel F, Bastías A, Casado A, Amthauer R, Concha MI. Apolipoprotein A-l, an antimicrobial protein in Oncorhynchus mykiss: evaluation of its expression in primary defence barriers and plasma levels in sick and healthy fish. Fish Shellfish Immunol. 2007:23(1):197-209.

13. Sigel S, Bunk S, Meergans T, Doninger B, Stich K, Stulnig T, Derfler K, Hoffmann J, Deininger S, von Aulock S, et al. Apolipoprotein B100 is a suppressor of Staphylococcus aureus-induced innate immune responses in humans and mice. Eur J Immunol. 2012:42(11):2983-9.

14. Wang $C Q$, Yang $C S$, Yang Y, Pan F, He LY, Wang AM. An apolipoprotein E mimetic peptide with activities against multidrug-resistant bacteria and immunomodulatory effects. J Pept Sci. 2013;19(12):745-50.

15. Janciauskiene SM, Bals R, Koczulla R, Vogelmeier C, Köhnlein T, Welte T. The discovery of a1-antitrypsin and its role in health and disease. Respir Med. 2011;105(8):1129-39

16. Wang G, Li X, Wang Z. APD2: the updated antimicrobial peptide database and its application in peptide design. Nucleic Acids Res. 2009;37(Database issue):D933-7.

17. Altschul SF, Gish W, Miller W, Myers EW, Lipman DJ. Basic local alignment search tool. J Mol Biol. 1990;215(3):403-10.

18. Biasini M, Bienert S, Waterhouse A, Arnold K, Studer G, Schmidt T, Kiefer F, Cassarino TG, Bertoni M, Bordoli L, et al. SWISS-MODEL: modelling protein tertiary and quaternary structure using evolutionary information. Nucleic Acids Res. 2014;42(Web Server issue):W252-8.

19. Bordoli L, Kiefer F, Arnold K, Benkert P, Battey J, Schwede T. Protein structure homology modeling using SWISS-MODEL workspace. Nat Protocols. 2008;4(1):1-13.

20. Kiefer F, Arnold K, Kunzli M, Bordoli L, Schwede T. The SWISS-MODEL repository and associated resources. Nucleic Acids Res. 2009;37(Database issue):D387-92. 
21. Guex N, Peitsch MC, Schwede T. Automated comparative protein structure modeling with SWISS-MODEL and Swiss-PdbViewer: a historical perspective. Electrophoresis. 2009;30(S1):S162-73.

22. Kopp J, Schwede T. The SWISS-MODEL repository: new features and functionalities. Nucleic Acids Res. 2006;34(Database issue):D315-8.

23. Arnold K, Bordoli L, Kopp J, Schwede T. The SWISS-MODEL workspace: a web-based environment for protein structure homology modelling. Bioinformatics. 2006;22(2):195-201.

24. Yang J, Yan R, Roy A, Xu D, Poisson J, Zhang Y. The I-TASSER Suite: protein structure and function prediction. Nat Meth. 2015;12(1):7-8.

25. Pettersen EF, Goddard TD, Huang CC, Couch GS, Greenblatt DM, Meng EC, Ferrin TE. UCSF Chimera-a visualization system for exploratory research and analysis. J Comput Chem. 2004;25(13):1605-12.

26. Gautier R, Douguet D, Antonny B, Drin G. HELIQUEST: a web server to screen sequences with specific alpha-helical properties. Bioinformatics. 2008;24(18):2101-2.

27. Raussens V, Ruysschaert J-M, Goormaghtigh E. Protein concentration is not an absolute prerequisite for the determination of secondary structure from circular dichroism spectra: a new scaling method. Anal Biochem. 2003: 319(1):114-21.

28. Murata T, Tseng W, Guina T, Miller SI, Nikaido H. PhoPQ-mediated regulation produces a more robust permeability barrier in the outer membrane of Salmonella enterica serovar typhimurium. J Bacteriol. 2007; 189(20):7213-22.

29. Li Y, Powell DA, Shaffer SA, Rasko DA, Pelletier MR, Leszyk JD, Scott AJ, Masoudi A, Goodlett DR, Wang X, et al. LPS remodeling is an evolved survival strategy for bacteria. Proc Natl Acad Sci U S A. 2012;109(22):8716-21.

30. Gupta K, Singh S, van Hoek ML. Short, Synthetic Cationic Peptides Have Antibacterial Activity against Mycobacterium smegmatis by Forming Pores in Membrane and Synergizing with Antibiotics. Antibiotics (Basel). 2015;4(3):358-78

31. Dean SN, Bishop BM, van Hoek ML. Natural and synthetic cathelicidin peptides with anti-microbial and anti-biofilm activity against Staphylococcus aureus. BMC Microbiol. 2011;11:114.

32. Nelson CA. The binding of detergents to proteins. I. The maximum amount of dodecyl sulfate bound to proteins and the resistance to binding of several proteins. J Biol Chem. 1971;246(12):3895-901.

33. Wang W, Smith DK, Moulding K, Chen HM. The dependence of membrane permeability by the antibacterial peptide cecropin $B$ and its analogs, CB-1 and CB-3, on liposomes of different composition. J Biol Chem. 1998;273(42):27438-48.

34. Turner J, Cho Y, Dinh NN, Waring AJ, Lehrer RI. Activities of LL-37, a cathelin-associated antimicrobial peptide of human neutrophils. Antimicrob Agents Chemother. 1998;42(9):2206-14.

35. Formaggio F, Toniolo C. Electronic and vibrational signatures of peptide helical structures: a tribute to Anton Mario Tamburro. Chirality. 2010;22(1E):E30-9.

36. Roccatano D, Colombo G, Fioroni M, Mark AE. Mechanism by which 2,2,2-trifluoroethanol/water mixtures stabilize secondary-structure formation in peptides: a molecular dynamics study. Proc Natl Acad Sci U S A. 2002;99(19):12179-84.

37. Kinoshita M, Okamoto Y, Hirata F. Peptide conformations in alcohol and water: analyses by the reference interaction site model theory. J Am Chem Soc. 2000;122(12):2773-9.

38. Hirota N, Mizuno K, Goto Y. Group additive contributions to the alcoholinduced a-helix formation of melittin: implication for the mechanism of the alcohol effects on proteins. J Mol Biol. 1998;275(2):365-78.

39. Travis SM, Anderson NN, Forsyth WR, Espiritu C, Conway BD, Greenberg EP, McCray PB, Lehrer RI, Welsh MJ, Tack BF. Bactericidal activity of mammalian cathelicidin-derived peptides. Infect Immun. 2000;68(5):2748-55.

40. Amer LS, Bishop BM, van Hoek ML. Antimicrobial and antibiofilm activity of cathelicidins and short, synthetic peptides against Francisella. Biochem Biophys Res Commun. 2010;396(2):246-51.

41. Limoli DH, Rockel AB, Host KM, Jha A, Kopp BT, Hollis T, Wozniak DJ. Cationic antimicrobial peptides promote microbial mutagenesis and pathoadaptation in chronic infections. PLoS Pathog. 2014;10(4):e1004083.

42. Shi W, Li C, Li M, Zong X, Han D, Chen Y. Antimicrobial peptide melittin against Xanthomonas oryzae pv. oryzae, the bacterial leaf blight pathogen in rice. Appl Microbiol Biotechnol. 2016;100(11):5059-67.

43. Navab M, Anantharamaiah GM, Hama S, Garber DW, Chaddha M, Hough G, Lallone R, Fogelman AM. Oral administration of an Apo A-I mimetic peptide synthesized from D-Amino acids dramatically reduces atherosclerosis in mice independent of plasma cholesterol. Circulation. 2002;105(3):290-2.

44. Beck WHJ, Adams CP, Biglang-awa IM, Patel AB, Vincent H, Haas-Stapleton EJ, Weers PMM. Apolipoprotein A-I binding to anionic vesicles and lipopolysaccharides: Role for lysine residues in antimicrobial properties. Biochim Biophys Acta Biomembr. 2013;1828(6):1503-10.

45. Kelly BA, Neil SJ, McKnight Á, Santos JM, Sinnis P, Jack ER, Middleton DA, Dobson CB. Apolipoprotein E-derived antimicrobial peptide analogues with altered membrane affinity and increased potency and breadth of activity. FEBS J. 2007;274(17):4511-25.

46. Concha MI, Molina S, Oyarzún C, Villanueva J, Amthauer R. Local expression of apolipoprotein A-I gene and a possible role for HDL in primary defence in the carp skin. Fish Shellfish Immunol. 2003;14(3):259-73.

47. Ulevitch RJ, Johnston AR, Weinstein DB. New function for high density lipoproteins. Their participation in intravascular reactions of bacterial lipopolysaccharides. J Clin Invest. 1979:64(5):1516-24.

48. Dobson CB, Sales SD, Hoggard P, Wozniak MA, Crutcher KA. The receptorbinding region of human apolipoprotein $\mathrm{E}$ has direct anti-infective activity. J Infect Dis. 2006;193(3):442-50.

49. Gooptu B, Lomas DA. Conformational pathology of the serpins: themes, variations, and therapeutic strategies. Annu Rev Biochem. 2009;78:147-76.

50. Luo LY, Jiang $W$. Inhibition profiles of human tissue kallikreins by serine protease inhibitors. Biol Chem. 2006;387(6):813-6.

51. Janciauskiene S, Nita I, Subramaniyam D, Li Q, Lancaster Jr JR, Matalon S. Alpha1-antitrypsin inhibits the activity of the matriptase catalytic domain in vitro. Am J Respir Cell Mol Biol. 2008;39(6):631-7.

52. Petrache I, Fijalkowska I, Medler TR, Skirball J, Cruz P, Zhen L, Petrache HI, Flotte TR, Tuder RM. alpha-1 antitrypsin inhibits caspase-3 activity, preventing lung endothelial cell apoptosis. Am J Pathol. 2006;169(4):1155-66.

53. Churg A, Dai J, Zay K, Karsan A, Hendricks R, Yee C, Martin R, MacKenzie R, Xie C, Zhang L, et al. Alpha-1-antitrypsin and a broad spectrum metalloprotease inhibitor, RS113456, have similar acute anti-inflammatory effects. Lab Invest. 2001;81(8):1119-31.

54. Kalsheker N, Morley S, Morgan K. Gene regulation of the serine proteinase inhibitors a1-antitrypsin and a1-antichymotrypsin. Biochem Soc Trans. 2002;30(2):93-8.

55. Bergin DA, Reeves EP, Hurley $K$, Wolfe $R$, Jameel $R$, Fitzgerald $S$, McElvaney NG. The circulating proteinase inhibitor alpha-1 antitrypsin regulates neutrophil degranulation and autoimmunity. Sci Transl Med. 2014;6(217):217ra211

56. Libert C, Van Molle W, Brouckaert P, Fiers W. alpha1-Antitrypsin inhibits the lethal response to TNF in mice. J Immunol. 1996;157(11):5126-9. 1.

57. Spencer LT, Paone G, Krein PM, Rouhani FN, Rivera-Nieves J, Brantly ML. Role of human neutrophil peptides in lung inflammation associated with alpha1-antitrypsin deficiency. Am J Physiol Lung Cell Mol Physiol. 2004; 286(3):L514-20.

58. Chambers JP, Yu JJ, Jupelli M, Weintraub ST, Lopez-Ribot JL, Valdes JJ, Arulanandam BP. Alpha-1 antitrypsin is markedly decreased following pulmonary F. tularensis challenge. Front Cell Infect Microbiol. 2011;1:20.

59. Sallenave JM. Antimicrobial activity of antiproteinases. Biochem Soc Trans. 2002;30(2):111-5.

60. Cantin AM, Woods DE. Aerosolized prolastin suppresses bacterial proliferation in a model of chronic Pseudomonas aeruginosa lung infection. Am J Respir Crit Care Med. 1999;160(4):1130-5.

61. Shapiro L, Pott GB, Ralston AH. Alpha-1-antitrypsin inhibits human immunodeficiency virus type 1. FASEB J. 2001;15(1):115-22.

62. Congote LF. The C-terminal 26-residue peptide of serpin $A 1$ is an inhibitor of HIV-1. Biochem Biophys Res Commun. 2006;343(2):617-22.

63. Jia Q, Jiang X, Yu F, Qiu J, Kang X, Cai L, Li L, Shi W, Liu S, Jiang S, et al. Short cyclic peptides derived from the C-terminal sequence of alpha1antitrypsin exhibit significant anti-HIV-1 activity. Bioorg Med Chem Lett. 2012;22(7):2393-5.

64. Olaitan AO, Morand S, Rolain JM. Mechanisms of polymyxin resistance: acquired and intrinsic resistance in bacteria. Front Microbiol. 2014;5:643.

65. O'Driscoll T, Crank CW. Vancomycin-resistant enterococcal infections: epidemiology, clinical manifestations, and optimal management. Infect Drug Resist. 2015;8:217-30.

66. Spagnolo AM, Orlando P, Panatto D, Amicizia D, Perdelli F, Cristina ML. Staphylococcus aureus with reduced susceptibility to vancomycin in healthcare settings. J Prev Med Hyg. 2014;55(4):137-44. 
67. Carr C, Morrison DC. Mechanism of polymyxin B-mediated lysis of lipopolysaccharide-treated erythrocytes. Infect Immun. 1985;49(1):84-9.

68. Saberwal G, Nagaraj R. Cell-lytic and antibacterial peptides that act by perturbing the barrier function of membranes: facets of their conformational features, structure-function correlations and membraneperturbing abilities. Biochim Biophys Acta. 1994;1197(2):109-31.

Submit your next manuscript to BioMed Central and we will help you at every step:

- We accept pre-submission inquiries

- Our selector tool helps you to find the most relevant journal

- We provide round the clock customer support

- Convenient online submission

- Thorough peer review

- Inclusion in PubMed and all major indexing services

- Maximum visibility for your research

Submit your manuscript at www.biomedcentral.com/submit 